\title{
Retrospective analysis of MR imaging characteristics and demographic characteristics of Tropical Endomyocardial fibrosis in a tertiary care centre in South India
}

\author{
RV Leena
}

From 19th Annual SCMR Scientific Sessions

Los Angeles, CA, USA. 27-30 January 2016

\section{Background}

Cardiac MR is helpful in the diagnosis and prognosis of endomyocardial fibrosis[EMF]. Among the two types of endomyocardial fibrosis, tropical endomyocardial fibrosis is geographically restricted to tropical parts of Africa, Latin America and in the southern districts of India, especially along the coastal region of Kerala. Various toxic and environmental factors were postulated as the etiopathogenesis of tropical endomyocardial fibrosis.

Endomyocardial fibrotic wall thickening of apex and subvalvular regions of one or both ventricles results in restrictive pattern. Typical delayed enhancement pattern is the subendocardial enhancement which is prominent in the apex and extending up to the subvalvular regions

\section{Methods}

This study was done in a tertiary care centre in South India. 7 year retrospective analysis of all the cases of endomyocardial fibrosis, which were diagnosed on MRI were included in the study. Retrospective analysis was done using the search tool option in the RIS-PACS software provided by GE. Demographic characteristics, MRI findings and other associated findings were tabulated.

\section{Results}

A total of 11 cases were found, of which 9 were females and 2 were males. Most of the patients were young [less than 40 years]. The socio economic status showed mixed pattern, some $(\sim 2)$ from higher socioeconomic status and others from low to middle socioeconomic status. Place of living also was distributed between

Radiology, Chrisitian Medical College, Vellore, India various states in Indian subcontinent, and didn't pertain to any costal belt. None of the patients had eosinophilia.

Among the MRI findings, 3 patients had only left ventricular (LV) involvement, 3 patients had only right ventricular (RV) involvement, rest had biventricular involvement with RV involvement more than left ventricle involvement in 4 of them. Subendocardial enhancement was present in all. Two patients had associated mid myocardial enhancement in same or different chambers, hence a possibility of associated hypertrophic cardiomyopathy was also raised. Hypokinesia was present in the involved areas in 8 of the patients. Pulmonary arterial hypertension was seen in 5 patients. Thrombus was present in 2 patients. Associated cardiac cirrhosis was noted in 4 patients. One patient had tuberculous constrictive pericarditis and had underwent pericardial stripping . Presence of calcification was identified in 2 patients, who had additional CT sections. Most of the patients had normal LV systolic function. All the patients underwent medical management.

\section{Conclusions}

1. Apical obliteration with subendocardial enhancement is typical MRI finding

2. MRI findings can mimic Ebstine's anomaly, however subendocardial enhancement will give the diagnostic clue to EMF.

3. Presence of thrombus due to relative ventricular stasis is also common in EMF.

4. Absence of eosinophilia in the tropical EMF. Postulation of combination of factors leading to EMF may be hypothesized in our case series in view of variation in place of living among patients. 
Table 1

\begin{tabular}{|c|c|c|c|c|c|c|c|c|c|c|c|c|}
\hline $\begin{array}{l}\text { SI } \\
\text { No }\end{array}$ & Place of living & Age & sex & $\begin{array}{l}\text { Presence of } \\
\text { eosinophilia }\end{array}$ & $\begin{array}{l}\text { Chambers } \\
\text { involved }\end{array}$ & $\begin{array}{l}\text { Chambers } \\
\text { dilated }\end{array}$ & $\begin{array}{l}\text { Enhancement } \\
\text { pattern }\end{array}$ & $\begin{array}{l}\text { Regional wall } \\
\text { motion } \\
\text { Abnormality }\end{array}$ & $\begin{array}{l}\text { Presence of Pulmonary } \\
\text { arterial hypertension }\end{array}$ & $\begin{array}{c}\text { Ejection } \\
\text { fraction } \\
\text { [LV] }\end{array}$ & $\begin{array}{l}\text { Calcification } \\
\text { present }\end{array}$ & $\begin{array}{c}\text { Associated } \\
\text { Abnormalities }\end{array}$ \\
\hline 1 & Tamilnadu[TN] & 43 & M & No & LV & LA, LV & subendocardial & Present & Absent & normal & yes & nil \\
\hline 2 & $\begin{array}{c}\text { Andhrapradhesh } \\
\text { [AP] }\end{array}$ & 34 & $\mathrm{~F}$ & No & LV & LV & subendocardial & Present & Absent & normal & no & nil \\
\hline 3 & TN & 62 & $\mathrm{~F}$ & No & $R V>L V$ & RA & subendocardial & Present & Present & normal & no & $\begin{array}{l}\text { thrombus in RV, } \\
\text { cardiac cirrhosis }\end{array}$ \\
\hline 4 & West Bengal & 40 & $\mathrm{~F}$ & No & LV & RA, LA & $\begin{array}{l}\text { subendocardial, } \\
\text { midmyocardial }\end{array}$ & Absent & Present & normal & no & cardiac cirrhosis \\
\hline 5 & TN & 27 & $\mathrm{~F}$ & No & $R V>L V$ & RA & subendocardial & Absent & Absent & normal & yes & $\begin{array}{l}\text { thrombus in RA, LV, } \\
\text { cardiac cirrhosis }\end{array}$ \\
\hline 6 & Bihar & 43 & $\mathrm{~F}$ & No & $R V>L V$ & RA & $\begin{array}{l}\text { subendocardial, } \\
\text { midmyocardial }\end{array}$ & Present & Absent & normal & no & nil \\
\hline 7 & Pondicherry & 51 & $\mathrm{~F}$ & No & $R V>L V$ & RA & subendocardial & Present & Absent & reduced & no & nil \\
\hline 8 & Bihar & 30 & $\mathrm{~F}$ & No & RV & RA & subendocardial & Absent & Absent & normal & no & cardiac cirrhosis \\
\hline 9 & $\mathrm{AP}$ & 23 & M & No & $L V>R V$ & RA & subendocardial & Absent & Present & normal & no & $\begin{array}{l}\text { Tuberculous } \\
\text { constrictive } \\
\text { pericarditis }\end{array}$ \\
\hline 10 & Jharkhand & 32 & $\mathrm{~F}$ & No & RV & RA & subendocardial & Absent & Present & normal & no & nil \\
\hline 11 & TN & 61 & $\mathrm{~F}$ & No & RV & RA & subendocardial & Present & Present & normal & no & nil \\
\hline
\end{tabular}




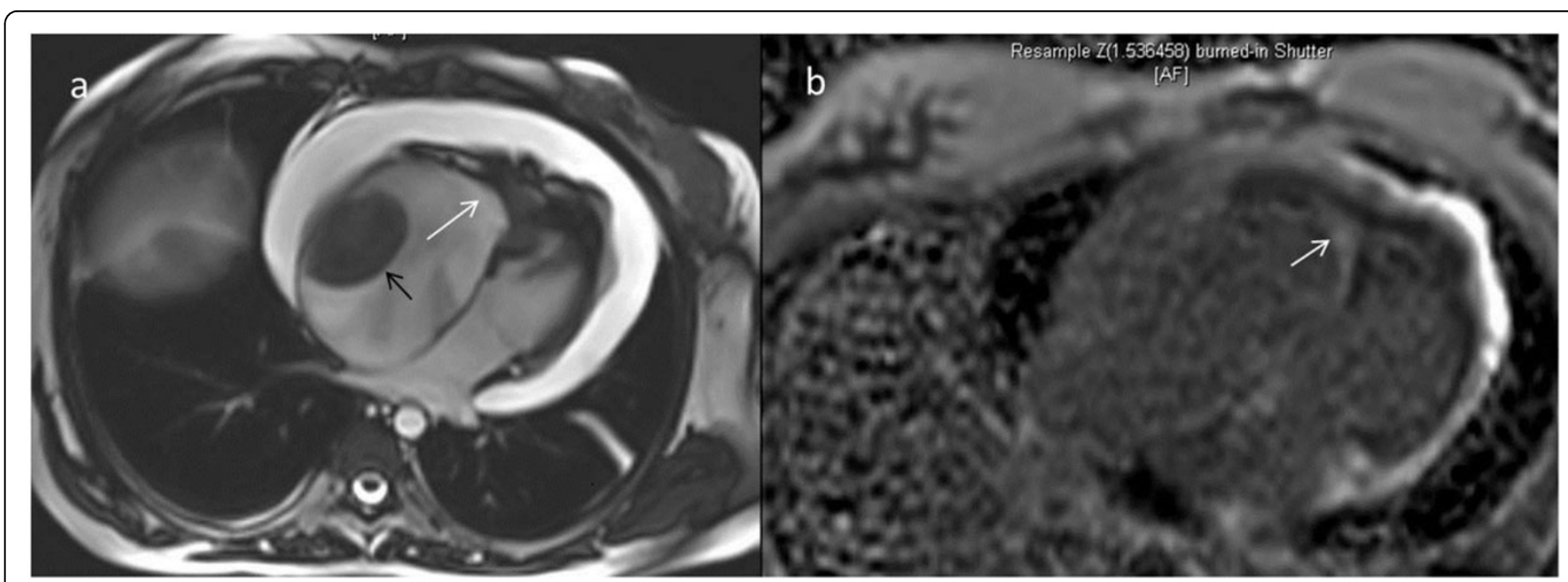

Figure 1 a) Four chamber view shows RV apex obliteration due to wall thickening [white arrow] and presence of thrombus[black arrow] in dilated right atrium b) Post gadolinium PSIR image shows subendocardial enhancement [white arrow].

Published: 27 January 2016

doi:10.1186/1532-429X-18-S1-P286

Cite this article as: Leena: Retrospective analysis of MR imaging

characteristics and demographic characteristics of Tropical

Endomyocardial fibrosis in a tertiary care centre in South India. Journal of

Cardiovascular Magnetic Resonance 2016 18(Suppl 1):P286.

\section{Submit your next manuscript to BioMed Central} and take full advantage of:

- Convenient online submission

- Thorough peer review

- No space constraints or color figure charges

- Immediate publication on acceptance

- Inclusion in PubMed, CAS, Scopus and Google Scholar

- Research which is freely available for redistribution 